\title{
Hemi-meningitis
}

\section{A focal sign heralding a multisystem necrotizing vasculitis}

\section{Figure Coronal brain MRI and sural nerve biopsy}
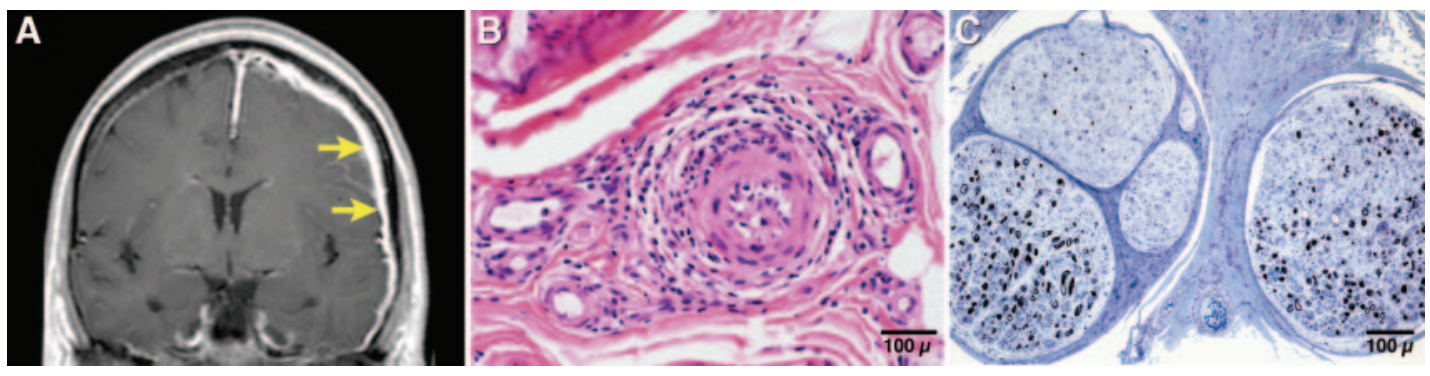

(A) Coronal brain MRI with gadolinium demonstrating pachymeningeal enhancement (arrows). Sural nerve biopsy: (B) Paraffin cross-section shows a large epineurial arteriole with vessel wall damage, luminal occlusion, and recanalization. Inflammatory mononuclear cells are present around and within the vessel wall. (C) Methylene blue-stained, semi-thin epoxy section shows both intrafascicular and interfascicular multifocal fiber loss. The fascicles on the upper left are essentially devoid of myelinated fibers whereas those on the lower left and on the right retain numerous myelinated fibers, some actively degenerating.

A 58-year-old woman developed arthralgias and diffuse headache. Brain MRI with gadolinium revealed unilateral left pachymeningeal enhancement (figure, A) but CSF analysis revealed no evidence of infection or neoplasm. Four months later, she developed mononeuritis multiplex, nasal mucosal crusting, episcleritis, and digital splinter hemorrhages. c-ANCA autoantibody titer was elevated but chest $\mathrm{X}$-ray and the serum creatinine level were normal. Nerve biopsy confirmed necrotizing vasculitis (figure, B and C). All clinical manifestations resolved after cyclophosphamide treatment.

The systemic features of this case are most consistent with Wegener granulomatosis, a necrotizing vasculitis with predilection for small vessels and diverse, often multifocal, neurologic manifestations. ${ }^{1}$ The meninges receive lateralized vascular supply in parallel with the brain, including extensive branches from the internal carotid and vertebral arteries. The strikingly unilateral nature of the meningitis suggested a vascular etiology.

Dean M. Wingerchuk, MD, MSc, FRCP(C), P. James B. Dyck, MD, and Lester E. Mertz, MD, Scottsdale, AZ (D.M.W., L.E.M.) and Rochester, MN (P.J.B.D.)

Disclosure: The authors report no disclosures.

Address correspondence and reprint requests to Dr. Dean M. Wingerchuk, Department of Neurology, 13400 E Shea Blvd., Scottsdale,AZ 85259; wingerchuk.dean@mayo.edu.

1. Nishino H, Rubino FA, DeRemee RA, Swanson JW, Parisi JE. Neurological involvement in Wegener's granulomatosis: an analysis of 324 consecutive patients at the Mayo Clinic. Ann Neurol 1993;33:4-9. 


\section{Neurology}

\section{Hemi-meningitis: A focal sign heralding a multisystem necrotizing vasculitis}

Dean M. Wingerchuk, P. James B. Dyck and Lester E. Mertz

Neurology 2008;70;2014

DOI 10.1212/01.wnl.0000312520.71743.54

This information is current as of May 19, 2008

\section{Updated Information \& Services}

References

Citations

Subspecialty Collections

Permissions \& Licensing

Reprints including high resolution figures, can be found at: http://n.neurology.org/content/70/21/2014.full

This article cites 1 articles, 0 of which you can access for free at: http://n.neurology.org/content/70/21/2014.full\#ref-list-1

This article has been cited by 2 HighWire-hosted articles: http://n.neurology.org/content/70/21/2014.full\#\#otherarticles

This article, along with others on similar topics, appears in the following collection(s):

All Clinical Neurology

http://n.neurology.org/cgi/collection/all_clinical_neurology

All Medical/Systemic disease

http://n.neurology.org/cgi/collection/all_medical_systemic_disease

MRI

http://n.neurology.org/cgi/collection/mri

Peripheral neuropathy

http://n.neurology.org/cgi/collection/peripheral_neuropathy

Vasculitis

http://n.neurology.org/cgi/collection/vasculitis

Information about reproducing this article in parts (figures,tables) or in its entirety can be found online at:

http://www.neurology.org/about/about_the_journal\#permissions

Information about ordering reprints can be found online:

http://n.neurology.org/subscribers/advertise

Neurology ${ }^{\circledR}$ is the official journal of the American Academy of Neurology. Published continuously since 1951, it is now a weekly with 48 issues per year. Copyright . All rights reserved. Print ISSN: 0028-3878. Online ISSN: 1526-632X.

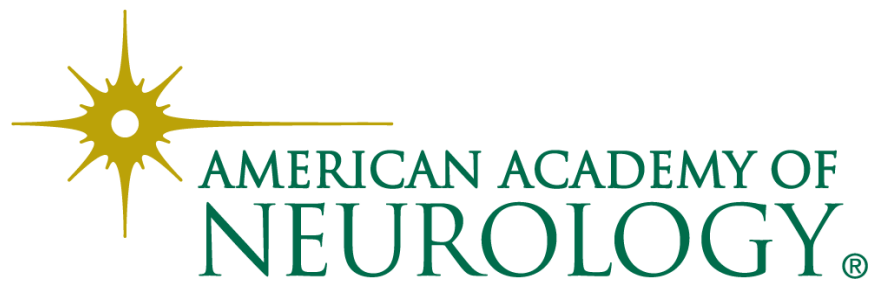

